\title{
Efektivitas Sinkronisasi Estrus dengan Metode Ovsynch pada Induk Sapi PO Akseptor Belgian Blue
}

\section{(Effectiveness of Estrus Synchronization using Ovsynch Method on Ongole Cross Cattle's as an Acceptors of Belgian Blue)}

\author{
Prihandini PW, Primananda M, Dikman DM, Karnadi D, Pamungkas D \\ Loka Penelitian Sapi Potong \\ Jalan Pahlawan Grati, Bebekan Lor, Ranu Klindungan, Kec. Grati, Pasuruan, Jawa Timur 67184 \\ syahada01@yahoo.com
}

\begin{abstract}
The high demand for meat makes the government have to carry out self-sufficiency in meat. Efforts to increase and improve cattle population can be done by increasing the use of Artificial Insemination (AI) technology, Embryo Tansfer (ET) and optimizing natural mating. This study aimed to determine and observe the effect of estrous synchronization using Ovsyhnc method on estrous response and conception rate in PO cattle's Belgian Blue acceptors. The study was conducted for 4 months, in April until July 2019, in Beef Cattle Research Station, Grati, Pasuruan, East Java. About 17 PO cows were given Ovsynch treatment with 2 (two) GnRh injections and 1 (one) injection of PGF2alfa. The order of the Ovsynch method was on day 0, injected GnRH (Fertagyl) 2.5 cc intramuscular, on day 7 inject PGF2Alfa 5cc intramuscular, on day 9 again inject GnRH (Fertagyl) 2.5 cc intramuscular. AI was done after the cow showed signs of estrous. The results showed that the estrous response shown by Ovsynh method PO cattle was $76.47 \%$ and the pregnancy rate obtained was $23,07 \%$. The study concluded that the Ovsynch method showed a moderately estrous response but the percentage of pregnancy results of the artificial insemination of BB was relatively moderate.
\end{abstract}

Key words: Estrous synchronization, Ovsynch, PO cattle, artificial insemination

\begin{abstract}
ABSTRAK
Tingginya permintaan masyarakat atas kebutuhan daging membuat pemerintah harus melaksanakan swasembada daging. Pemerintah melakukan peningkatan jumlah populasi sapi dengan cara meningkatkan penyediaan dan perbaikan bibit sapi. Upaya peningkatan dan perbaikan populasi sapi dilakukan dengan cara peningkatan penggunaan teknologi Inseminasi Buatan (IB), Embrio Tansfer (ET) dan optimalisasi kawin alam. Penelitian ini bertujuan untuk mengetahui dan mengamati pengaruh sinkronisasi berahi dengan metode Ovsynch terhadap respon berahi dan pregnancy rate pada sapi PO akseptor semen Belgian Blue. Penelitian dilakukan selama 4 bulan, pada bulan april hingga bulan juli tahun 2019, dikandang percobaan Loka Penelitian Sapi Potong, Grati, Pasuruan, Jawa Timur. Tujuh belas ekor induk sapi PO diberikan perlakuan Ovsynch dengan 2 (dua) kali injeksi GnRh dan 1 (satu) kali injeksi PGF2alfa. Urutan metode Ovsynch sebagai berikut : pada hari 0, diinjeksikan GnRH (Fertagyl) 2,5 cc intramuscular, pada hari ke 7 injeksi PGF2Alfa 5cc intramuscular, pada hari ke 9 injeksi GnRH ( Fertagyl) 2,5 cc intramuscular Pelaksanaan IB dilakukan setelah induk memperlihatkan tanda-tanda berahi. Hasil penelitian menunjukkan bahwa respon berahi sapi induk PO hasil metode Ovsynch 76,47\% dan pregnancy rate yang diperoleh adalah 23,07 \%. Penelitian
\end{abstract}


menyimpulkan bahwa metode Ovsynch memperlihatkan respon berahi yang cukup tinggi namun persentase kebuntingan hasil IB dengan semen BB masih tergolong sedang.

Kata kunci: Sinkronisasi berahi, Ovsynch, induk sapi PO, inseminasi buatan

\section{PENDAHULUAN}

Seiring dengan bertambahnya jumlah penduduk Indonesia, maka kebutuhan masyarakat terhadap pangan khususnya pangan hewani dari tahun ke tahun semakin meningkat. Tingginya permintaan masyarakat atas kebutuhan daging membuat pemerintah harus melaksanakan swasembada daging. Untuk pemenuhan kebutuhan daging sapi maka pemerintah melakukan beberapa upaya yang harus dilakukan, salah satunya peningkatan jumlah populasi sapi dengan cara meningkatkan penyediaan dan perbaikan bibit sapi. Peningkatan penyediaan bibit sapi dilakukan melalui peningkatan efisiensi reproduksi ternak sehingga setiap ternak betina produktif dapat melahirkan satu ekor anak dalam setahun (Darussalam 2016), sedangkan perbaikan bibit sapi dapat dilakukan dengan pengembangan sapi Belgian Blue (BB). Upaya peningkatan dan perbaikan populasi sapi dilakukan dengan cara peningkatan penggunaan teknologi Inseminasi Buatan (IB), Embrio Tansfer (ET) dan optimalisasi kawin alam.

Keberhasilan teknologi IB dipengaruhi oleh berbagai faktor, diantaranya faktor manajemen sumber daya manusia (peternak dan inseminator), faktor betina (umur produktis dan siklus reproduksi normal) dan kualitas semen yang diinseminasikan (straw BB). Pelaksanaan IB umumnya dilakukan melalui perkawinan dengan melihat gejala estrus oleh inseminator pada sapi betina, namun IB dapat dilakukan melalui sinkronisasi estrus terutama untuk perkawinan secara serentak seperti pada program Gertak Berahi Inseminasi Buatan (GBIB) maupun Upaya Khusus Sapi Induk Wajib Bunting (UPSUS SIWAB) (Affandhy et al. 2017).

Sinkronisasi adalah suatu pengendalian estrus yang dilakukan pada sekelompok ternak betina sehat dengan memanipulasi mekanisme hormonal, sehingga keserentakan estrus dan ovulasi dapat terjadi pada hari yang sama atau dalam kurun 2 atau 3 hari setelah perlakuan dilepas, sehingga IB dapat dilakukan serentak (Toelihere 1985). Sikronisasi ini mengarah pada hambatan ovulasi dan penundaan aktivitas regresi Corpus Luteum (CL) (Hafez 1993). Hormon yang digunakan dalam sinkronisasi estrus adalah hormon progesteron dan hormon prostaglandin, serta hormon pendukung lainnya dapat berupa Gonadotrophin Releasing Hormone $(\mathrm{GnRH})$, Follicle Stimulating Hormone (FSH), Luteinizing Hormone (LH) dan lainnya. Sinkronisasi estrus dapat dilakukan dengan beberapa metode yaitu metode Ovsynch, Cosynch, Controle Internal Drugs Release (CIDR) dan Progesterone Releasing Intravaginal Devices (PRID).

Sinkronisasi berahi yang dikombinasikan dengan sinkronisasi ovulasi, menyebabkan berahi dan ovulasi terjadi secara serentak sehingga IB dilakukan pada waktu yang telah ditentukan (Fixed Time AI) disebut dengan metode Ovsynch. Metode ini dari segi hormonal melakukan kombinasi antara hormon GnRH dan PGF2alfa. Keberhasilan metode sinkronisasi estrus ini dapat dilihat dari gejala estrus yang muncul dan persentase kebuntingan yang diperoleh.

Penelitian ini bertujuan untuk mengetahui pengaruh metode Ovsyhnc terhadap respon berahi pada sapi PO akseptor BB. Selain itu penelitian juga bertujuan untuk memberikan informasi ilmiah bagi akademisi dan peneliti serta sumber pengetahuan bagi masyarakat peternak tentang pengaruh perlakuan sinkronisasi berahi terhadap respon berahi pada sapi PO akseptor BB. 


\section{MATERI DAN METODE}

\section{Materi penelitian}

Materi yang digunakan sebanyak 17 ekor induk sapi Peranakan Ongole (PO) dengan kriteria sapi induk yang beranak minimal satu kali, bobot badan (BB) diatas $350 \mathrm{~kg}$ dan Skor Kondisi Tubuh (SKT) dengan nilai 3 ( skala 1-5). Pakan yang diberikan pada ternak selama penelitian terdiri dari hijauan dan konsentrat dengan kandungan protein kasar $(\mathrm{PK}) \geq 16 \%$ dan total digestible nutrient $(\mathrm{TDN}) \geq 65 \%$.

\section{Waktu dan tempat penelitian}

Penelitian dilakukan selama 4 bulan, pada bulan April - Juli tahun 2019, di kandang percobaan Loka Penelitian Sapi Potong, Grati, Pasuruan, Jawa Timur.

\section{Metode penelitian}

\section{Alat dan bahan penelitian}

Alat dan bahan penelitian yang digunakan adalah : Hormon GnRh (Fertagyl $^{\mathrm{TM}}$. Intervet Schering Plough Animal Health. Jerman), hormon PGF2alfa (Alfaglandin ${ }^{\circledR}$ C, Alfasan, Woerden Holland), straw BB, spuit 3 cc, kapas alkohol, dettol, gel, glove karet, glove panjang, jarum $18 \mathrm{G}$, gun IB, plastik sheet, N2 cair, kapas, gunting stainless, pinset stainless, gunting straw.

\section{Prosedur penelitian}

\section{Metode Ovsynch}

Tujuh belas ekor induk sapi PO diberikan perlakuan Ovsynch dengan 2 (dua) kali injeksi GnRh dan 1 (satu) kali injeksi PGF2alfa. Urutan metode Ovsynch sebagai berikut: pada hari 0, diinjeksikan GnRH (Fertagyl) 2,5 cc intramuscular, kemudian pada hari ke 7 injeksikan PGF2Alfa (Alfaglandin) 5cc intramuscular, selanjutnya pada hari ke 9 kembali injeksikan GnRH (Fertagyl) 2,5 cc intramuscular, pelaksanaan IB dilakukan setelah induk memperlihatkan tanda-tanda berahi.

\section{Pelaksanaan IB}

Pelaksanaan IB pada 17 ekor induk PO dilakukan setelah muncul tanda-tanda berahi, yaitu apabila dari vulva induk keluar lendir bening, vulva terasa panas, agak membengkak dan memerah. Pelaksanaan IB paling baik dilakukan pada saat puncak berahi dan maksimal 6 jam setelah puncak berahi untuk memperoleh persentase kebuntingan yang tinggi.

\section{Variabel yang diukur}

Variabel yang diukur adalah (1) persentase respon berahi induk yang di Ovsynch yaitu munculnya atau tidak tanda-tanda berahi, yaitu vulva mengeluarkan lendir bening baik itu tanpa di palpasi per rectal maupun setelah di-palpasi per rectal, vulva 
kemerahan, terasa hangat dan agak bengkak dan (2) pregnancy rate (PR) (persentase sapi betina yang bunting berdasarkan pemeriksaan palpasi per rectal dibandingkan dengan jumlah akseptor yang di IB).

\section{Analisis data}

Rumus yang digunakan untuk melihat tingkat respon induk yang di Ovsynch.

Tingkat respon $=\frac{\sum \text { induk.sapi.yang.respon }}{\sum \text { induk.sapi.yang.diOvsynch }} \times 100 \%$

Penjelasan PR dapat dirumuskan sebagai berikut :

$$
P R=\frac{\text { Jumlah betina bunting }}{\text { Jumlah Akseptor yang di } I B} \times 100 \%
$$

\section{HASIL DAN PEMBAHASAN}

\section{Persentase respon berahi}

Persentase respon berahi yang ditandai dengan munculnya tanda-tanda berahi dari induk yang di Ovsynch adalah 76,47 \%. Respon berahi yang muncul pada 13 induk dari 17 induk yang disinkronisasi ditandai dengan adanya lendir bening yang keluar, vulva terasa hangat, memerah dan agak bengkak. Respon berahi pada perlakuan Ovsynch disebabkan karena Hipofisa Anterior pada sapi induk PO yang disinkronisasi merespon terhadap penyuntikan GnRH eksogen dan estradiol. GnRH eksogen akan menstimulasi Hipofisa Anterior untuk mensekresi FSH dan LH. FSH bekerja pada tahap awal perkembangan folikel dan dibutuhkan untuk pembentukan folikel antrum. FSH dan LH merangsang folikel ovarium untuk mensekresikan estrogen. Menjelang waktu ovulasi konsentrasi hormon estrogen mencapai suatu tingkatan yang cukup tinggi untuk menekan produksi FSH dan dengan pelepasan LH menyebabkan terjadinya ovulasi dengan menggertak pemecahan dinding folikel dan pelepasan ovum. Setelah ovulasi maka akan terbentuk Corpus Luteum (CL) dan ketika tidak bunting maka PGF2alfa dari uterus akan melisiskan CL. Tetapi jika terjadi kebuntingan maka CL akan terus dipertahankan supaya konsentrasi progesteron tetap tinggi untuk menjaga kebuntingan (Hafez \& Hafez 2000).

Tabel 1. Persentase berahi induk PO dengan metode Ovsynch

\begin{tabular}{lccc}
\hline \hline Perlakuan & $\Sigma$ (ekor) yang respon & $\begin{array}{c}\Sigma \text { (ekor) yang } \\
\text { tidak respon }\end{array}$ & Persentase berahi (\%) \\
\hline Metode Ovsynch & 13 & 4 & 76,47 \\
\hline
\end{tabular}

Hasil penelitian ini didukung oleh penelitian Darussalam (2016) dimana persentase ternak yang memperlihatkan gejala berahi dari tiga metode sinkronisasi masing-masing adalah perlakuan GnRH tunggal (A) 0\% kemudian metode Ovsynch (B) 100\% dan Heatsynch (C) 100\%. Begitu juga dengan hasil penelitian dari Mardiansyah et al. (2016) bahwa persentase berahi pada sapi Bali setelah dilakukan sinkronisasi berahi menunjukkan tidak ada perbedaan nyata $(\mathrm{P}>0,05)$ terhadap sapi Bali dara dan induk dengan persentase estrus mencapai 100 \%. Pada metode Ovsynch penyuntikan GnRH berperan untuk memicu sekresi puncak LH melalui penyuntikan GnRH pada fase 
folikuler, dengan adanya tambahan GnRH eksternal maka akan menstimulasi Hipotalamus dan Hipofisa Anterior untuk mensekresikan FSH dan LH yang akan memicu pertumbuhan folikel di ovarium. Selanjutnya dengan penyuntikan PGF2alfa untuk melisiskan CL jika ada, kemudian dilanjutkan penyuntikan GnRH kedua untuk lebih meningkatkan sekresi LH dengan pelepasan LH menyebabkan terjadinya ovulasi dengan menggertak pemecahan dinding folikel dan pelepasan ovum (Sonjaya et al. 2007).

Ketika diinjeksi GnRH pada hari -9 (Fixed Time $A I$ ) tetapi kondisi ovarium sapi tidak diketahui, maka GnRH eksogen akan memicu pelepasan LH yang menyebabkan ovulasi dan memulai siklus lagi jika pada saat itu ovarium memiliki folikel matang. Jika ada CL, GnRH akan memicu pelepasan FSH yang menciptakan kelompok baru folikel kemudian jika sapi baru saja ovulasi dalam 4-5 hari, GnRH tidak akan berfungsi (Pursley et al. 1997). Peranan PGF2alfa adalah luteolisis atau meregresi CL pada ternak dan memiliki fungsi alami untuk mengontrol siklus estrus.

Pada perlakuan Ovsynch yang menggunakan subtitusi pemberian GnRH kedua ini akan menginduksi ovulasi dan waktu IB dapat ditentukan secara tepat. Hal ini sesuai dengan pendapat Larson et al. (2006), bahwa metode Ovsynch dengan pemberian GnRH kedua akan mempercepat terjadinya induksi berahi.Tidak timbulnya gejala berahi pada sapi induk PO 4 dari 17 induk yang disinkronisasi mungkin disebabkan kelompok sapi yang disinkronisasi Hipofisa Anterior belum merespon terhadap penyuntikan hormon GnRH eksogen dan juga bisa disebabkan oleh keseimbangan energi negatif, dalam arti jumlah pakan yang dikonsumsi lebih sedikit dibanding energi yang keluar, seperti untuk proses kelahiran dan menyusui.

Pada kejadian silent heat dan sub estrus sebenarnya hormon LH mampu menumbuhkan folikel pada ovarium sehingga terjadi ovulasi, tetapi tidak cukup mampu dalam mendorong sintesa hormon estrogen oleh sel granulosa dari folikel de Graaf. Hal inilah yang menyebabkan tidak munculnya berahi. Penanganan kasus silent heat dan sub estrus dapat dilakukan dengan peningkatan kualitas pakan agar ternak mendapat nutrisi yang cukup sehingga mekanisme hormonal dalam tubuh dapat berjalan dengan baik (Hafez \& Hafez 2000).

\section{Pregnancy rate $(\mathrm{PR})$}

Pregnancy rate (PR) (persentase kebuntingan) dari induk yang di Ovsynch dengan palpasi per rectal dibandingkan dengan jumlah akseptor yang di IB adalah 23,07\%. Rendahnya keberhasilan kebuntingan disebabkan banyak faktor seperti kegagalan hormonal, reaksi individu induk dan rusaknya straw serta kegagalan pengamatan berahi. Persentase kebuntingan ini ditampilkan pada Tabel 2.

Tabel 2. Pregnancy rate (PR) induk yang di Ovsynch dengan melakukan palpasi per rectal

\begin{tabular}{lccc}
\hline \hline Perlakuan & $\Sigma$ (ekor) yang di IB & $\begin{array}{c}\Sigma \text { (ekor) yang } \\
\text { bunting }\end{array}$ & Persentase bunting (\%) \\
\hline Metode Ovsynch & 13 & 3 & 23,07 \\
\hline
\end{tabular}

Jumlah sapi PO yang telah di IB dengan straw BB yang diduga bunting yang ditentukan pada hari ke-21 setelah IB. Namun demikian, untuk memastikan kebuntingan sapi PO akseptor, maka pada bulan kedua hingga ketiga setelah IB dilakukan pemeriksaan kebuntingan (PKB) dengan metode palpasi per rektal. Hasil PKB menunjukkan bahwa 23,07\% sapi akseptor dinyatakan bunting. Hasil penelitian dari Saili 
et al. (2016) menyatakan bahwa keberhasilan kebuntingan induk sapi Bali yang diberi perlakuan sinkronisasi berahi menunjukkan bahwa 73,01\% sapi akseptor dinyatakan bunting dengan persentase kebuntingan tertinggi (81\%) ditunjukkan oleh sapi-sapi akseptor dengan kelompok umur 3-4 tahun, sedangkan sapi pada kelompok umur 5-6 tahun, mencapai persentase kebuntingan sebesar 64,52\%.

Berdasarkan hasil penelitian Fauzi et al. (2017), persentase kebuntingan sebesar 53\% untuk dara dengan injeksi PGF2alfa dan 63\% untuk dara tanpa injeksi PGF2 $\alpha$, persentase kebuntingan dihitung melalui evaluasi hasil pengamatan Non Return Rate. Pada penelitian yang dilakukan Bambang Purwanto et al. (2018), persentase kebuntingan dari berbagai jenis induk yang menjadi akseptor sapi BB adalah 45,51\%. Selanjutnya penelitian dari Sudarmaji et al. (2004) menunjukkan bahwa setelah penyuntikan pertama dengan PGF2alfa, persentase berahi sapi PO (67,39\%) lebih tinggi secara sangat nyata daripada sapi bali (39,13\%), dari semua sapi berahi setelah penyuntikan kedua. Angka kebuntingan sapi bali (83,33\%) lebih tinggi secara sangat nyata daripada sapi PO $(47,37 \%)$.

Rendahnya keberhasilan kebuntingan hasil IB straw BB dapat terjadi karena beberapa faktor diantaranya adalah keterampilan inseminator dalam menentukan waktu dan melaksanakan prosedur IB, fisiologi ternak, kualitas semen dan faktor lingkungan. Kemunculan tanda-tanda berahi pada sapi betina sangat mempengaruhi tingkat keberhasilan IB. Karakteristik lendir servik berperan penting terhadap keberhasilan konsepsi, kemunculan lendir servik dapat digunakan sebagai alat pendeteksi berahi untuk menentukan waktu inseminasi yang tepat dengan tujuan untuk mendapatkan peningkatan persentase kebuntingan (Bernardi et al. 2015).

Hormon PGF2alfa hanya berperan dalam meregresi CL untuk memperpendek siklus berahi dan mengembalikan siklus berahi pada fase folikuler. Hormon PGFalfa akan meregresi CL yang ditandai dengan berhentinya produksi progesteron. PGF2alfa yang digunakan dalam kegiatan sinkronisasi berahi bekerja sebagai bahan peregresi CL (Milvae 2000). Regresi CL yang disertai dengan turunnya jumlah hormon progesteron akan memberikan respon terhadap hipotalamus yang nantinya akan merangsang terjadinya proses pensekresian hormon-hormon berahi yaitu GnRH, FSH, estrogen, dan LH. Hormon esterogen yang muncul di dalam organ reproduksi betina sangat berpengaruh terhadap munculnya tanda-tanda berahi seperti perubahan fisik vulva menjadi bengkak, merah, hangat dan berlendir.

Tsiliganni et al. (2011) menyatakan pada saat berahi, hormon steroid dari ovarium mempengaruhi kondisi fisiko kimia lendir servik, hal tersebut menyebabkan lendi servik mempermudah laju spermatozoa. Herawati et al. (2012) menjelaskan bahwa keterampilan inseminator dalam mengamati tanda-tanda berahi, penanganan semen beku, pencairan kembali (thawing), serta kemampuan melaksanakan IB akan menentukan keberhasilan IB. Susilawati (2011) menambahkan bahwa posisi deposisi semen saat IB mempengaruhi tingkat keberhasilan IB, posisi deposisi semen 4+ memiliki efisiensi reproduksi lebih tinggi daripada posisi deposisi semen 4.

\section{KESIMPULAN}

Metode Ovsynch cukup efektif dalam menyerentakkan berahi dan menyerentakkan ovulasi pada induk sapi PO. Respon berahi yang ditampikan oleh sapi induk PO hasil metode Ovsynch 76,47\% dan pregnancy rate yang diperoleh adalah 23,07 \%. Penelitian lebih lanjut dengan sistem pengamatan yang lebih intensif perlu dilakukan agar 
keberhasilan inseminasi buatan dengan straw BB yang dinilai dengan persentase kebuntingan dapat ditingkatkan.

\section{UCAPAN TERIMA KASIH}

Kami mengucapkan terima kasih kepada Kepala Loka Penelitian Sapi Potong, para Peneliti dan Teknisi bapak Dadang Karnadi, Mohammad Zhofir dan ibu serta Anak Kandang dan UHL yang telah membantu berjalannya penelitian ini.

\section{DAFTAR PUSTAKA}

Affandhy L, Gultom AR, Aryogi. 2017. Tingkat keberhasilan program gertak berahi inseminasi buatan di Provinsi Sulawesi Tengah. Dalam: Puastuti W, Muharsini S, Inounu I, Tiesnamurti B, Kusumaningtyas E, Wina E, Herawati T, Hartati, Hutasoit R, penyunting. Prosiding Seminar Nasional Teknologi Peternakan dan Veteriner. Bogor (Indonesia): Pusat Penelitian dan Pengembangan Peternakan. hlm. 92-100.

Bernardi S., Rinaudo A, Marini P. 2015. Cervical mucus characteristics and hormonal status at insemination of holstein cows. Iranian J Vet Res. 17:45-49.

Darussalam. 2016. Pengaruh perlakuan sinkronisasi berahi terhadap respon berahi pada sapi bali induk pasca melahirkan [Skripsi]. [Makassar (Indonesia)]: Universitas Hasanuddin.

Fauzi MR, Suyadi, Susilawati T. 2017. Pengaruh pemberian prostaglandin f2 alpha terhadap waktu kemunculan berahi dan keberhasilan inseminasi buatan sapi brahman cross (bx) heifers. J Ilmu-Ilmu Peternakan 27:39-43.

Hafez ESE, Hafez B. 2000. Reproduction in farm animals. 7th ed. Philadelphia (USA): Lippincott Williams and Wilkins.

Hafez ESE. 1993. Reproduction in farm animal. 6th ed. Philadelphia (USA): Lea \& Febiger.

Herawati T, Anggraeni A, Praharani L, Utami D, Argiris A. 2012. Peran inseminator dalam keberhasilan inseminasi buatan pada sapi perah. Informatika Pertanian. 21:81-88.

Larson JE, Lamb GC, Stevenso JS, Johnson SK, Day M, Geary TW, Kesler DJ, Dejarnette JM, Schrick FN, Coztanzo A, Arseneau JD. 2006. Synchronization of estrus in sucled beef cows for detected estrous and artificial insemination using gonadotroping-releasing hormone, prostaglandin $\mathrm{f} 2 \alpha$, and progesteron. J Anim Sci. 71:61.

Mardiansyah, Yuliani E, Prasetyo S. 2016. Respon tingkah laku berahi, service per conception,non return rate, conception rate pada sapi bali dara dan induk yang disinkronisasi berahi dengan hormon progesteron. Jurnal Ilmu dan Teknologi Peternakan Indonesia. 2:134-143.

Milvae RA. 2000. Inter-relationships between endothelin and prostaglandinf $2 \alpha$ in korpus luteum function. J Reprod Fertil. 5:1-5.

Pursley JR, Kosorok MW, Wiltbank MC. 1997. Reproductive management of lactating dairy cows using synchronization of ovulation. J Dairy Sci. 80:301-306.

Purwanto B, Parlindungan O, Siswanti Y, Imron M,Setiawan Y. 2018. Embryo transfer and artificial insemination program of belgian blue cattle in Indonesia: Pregnancy rate, birth weight and calving ease. [Bogor(Indonesia)]: IPB University.

Saili T, Nafiu LO, Baa LO, Rahadi S, Napirah A, Sura IW, Lopulalan F. Efektivitas sinkronisasi estrus dan fertilitas spermatozoa hasil sexing pada sapi bali di Sulawesi Tenggara. 2016. Jurnal Veteriner. 18:1-7. 
Sonjaya, Abustam E, Pali MD, Tolleng L, Sudirman. 2007. Bahan ajar mata kuliah ilmu reproduksi ternak. Makassar (Indonesia): Fakultas Peternakan, Universitas Hasanuddin.

Sudarmaji, Malik A, Gunawan. 2004. Pengaruh penyuntikan prostaglandin terhadap persentase berahi dan angka kebuntingan sapi bali dan PO di Kalimantan Selatan [Skripsi]. [Banjarmasin (Indonesia)]: Universitas Islam Kalimantan.

Susilawati T. 2011. Tingkat keberhasilan inseminasi buatan dengan kualitas dan deposisi semen yang berbeda pada sapi peranakan ongole. J Ternak Tropika. 12:15-24.

Toelihere MR. 1985. Fisiologi reproduksi pada ternak. Bandung (Indonesia): Angkasa Bandung.

Tsiliganni T, Amiridis GS, Dovolou E, Menegatos L, Chadio S, Rizos D, Adan AG. 2011. Association between physical properties of cervical mucus and ovulation rate in superovulated cows. Can J Vet Res. 75:248-253. 